\title{
Effects of different nitrogen sources on growth, chlorophyll concentration, nitrate reductase activity and carbon and nitrogen distribution in Araucaria angustifolia
}

\author{
Mário L. Garbin ${ }^{1,2}$ and Lúcia R. Dillenburg ${ }^{*}$ \\ ${ }^{1}$ Departamento de Botânica, Universidade Federal do Rio Grande do Sul, Avenida Bento Gonçalves 9500, 91501- \\ 970, Porto Alegre, RS, Brasil. \\ ${ }^{2}$ Present address: Departamento de Ecologia, Universidade Federal do Rio de Janeiro, IB, CCS, IIha do Fundão, \\ 21941-970, Rio de Janeiro, RJ, Brasil.
}

*Corresponding author. lucia.dillenburg@ufrgs.br, tel.: 55-51-3308-7644, fax: 55-51-3308-6777. Received: 11 July 2008; Returned for revision: 31 August 2008; Accepted: 02 October 2008

The southern Brazilian highland plateau is a mosaic of two contrasting plant communities, Araucaria forests and grasslands, both differing in the relative abundances and spatial patterns of soil nitrate and ammonium. However, we still do not know the inorganic N preferences of one key species in this mosaic, Araucaria angustifolia, the dominant tree species in the Araucaria forests and an important tree species invading the adjacent grasslands. Growth responses measured in a greenhouse study demonstrated that the species prefers $\mathrm{NH}_{4}{ }^{+}$over $\mathrm{NO}_{3}{ }^{-}$as an inorganic $\mathrm{N}$ source. When provided alone, $\mathrm{NO}_{3}{ }^{-}$induced $\mathrm{N}$ deficiency symptoms: increases in root: shoot ratio, root branching and leaf mass per area, thickening of the shoot apexes and decreased mass-based chlorophyll and $\mathrm{N}$ concentrations of the young leaves. Nitrate-based nutrition also affected the whole plant $\mathrm{N}$ and carbon (C) distribution: young leaves accumulated less $\mathrm{N}$ and showed a larger $\mathrm{C}: \mathrm{N}$ ratio than mature leaves. The nitrate reductase activity (NRA) followed the pattern of root: shoot partitioning expected for temperate climate conifers, i.e. activity concentrated in roots. However, the presence of NRA even under sole $\mathrm{NH}_{4}{ }^{+}$nutrition indicates that plants may show constitutive levels of the enzyme, or that low levels of $\mathrm{NO}_{3}^{-}$(possibly formed by contamination of the growth media) can induce leaf NRA. We suggest that $A$. angustifolia uses ammonium as a preferential inorganic $\mathrm{N}$ source, and that this preference may favor a more successful establishment in grassland than in forest areas.

Key Words: Araucariaceae, ammonium, inorganic nitrogen, nitrate, nitrogen deficiency.

Efeitos de diferentes fontes de nitrogênio no crescimento, concentração de clorofila, atividade de nitrato redutase e distribuição de carbono e nitrogênio em Araucaria angustifolia: o planalto sul-brasileiro apresenta um mosaico de duas comunidades vegetais contrastantes, florestas com Araucaria e campos, que diferem em suas abundâncias relativas e nos padrões espaciais de nitrato e amônio no solo. Entretanto, ainda não se conhecem as preferências quanto ao N inorgânico de uma espécie-chave neste mosaico, Araucaria angustifolia, a espécie arbórea dominante nas florestas com Araucaria e uma importante espécie florestal que invade os campos adjacentes. Respostas de crescimento medidas em um estudo em casa de vegetação demonstraram que a espécie prefere $0 \mathrm{NH}_{4}{ }^{+}$ao $\mathrm{NO}_{3}{ }^{-}$, como fonte de $\mathrm{N}$ inorgânico. Quando fornecido isoladamente, $0 \mathrm{NO}_{3}{ }^{-}$induziu sintomas de deficiência de $\mathrm{N}$ : aumentos na razão raiz:parte aérea, ramificação radicular e massa foliar por área, espessamento dos ápices caulinares e redução 
nas concentrações por unidade de massa de clorofila e N, nas folhas jovens. Uma nutrição baseada em nitrato também afetou a distribuição de $\mathrm{N}$ e $\mathrm{C}$ na planta como um todo: as folhas jovens acumularam menos $\mathrm{N}$ e mostraram uma maior razão C:N do que as folhas maduras. A atividade da redutase do nitrato (ARN) seguiu o padrão de partição entre raiz e parte aérea esperado para coníferas de clima temperado (atividade concentrada nas raízes). No entanto, a presença de ARN mesmo sob nutrição exclusivamente com $\mathrm{NH}_{4}{ }^{+}$indica que as plantas devem ter níveis constitutivos da enzima ou que baixos níveis de $\mathrm{NO}_{3}{ }^{-}$(possivelmente gerado pela contaminação do meio de cultivo) podem induzir ARN. Sugere-se que A. angustifolia tem no amônio sua forma preferencial de $\mathrm{N}$ inorgânico e que esta preferência pode favorecer um melhor estabelecimento nos campos do que nas florestas.

Palavras-chave: Araucariaceae, amônio, deficiência de nitrogênio, nitrato, nitrogênio inorgânico.

\section{INTRODUCTION}

The southern Brazilian highland plateau is a mosaic of two contrasting plant communities, Araucaria forests and grasslands ("campos"), which differ not only in terms of vegetation structure and species composition, but also in terms of relative abundances and spatial patterns of inorganic nitrogen forms, nitrate $\left(\mathrm{NO}_{3}^{-}\right)$and ammonium $\left(\mathrm{NH}_{4}^{+}\right)$(Garbin et al., 2006). Thus, different strategies of nitrogen acquisition will affect the relative ability of plants to successfully establish in these contrasting soil environments. However, the inorganic $\mathrm{N}$ preferences of plant species which inhabit these plant communities are still poorly understood.

There are differences in the form of $\mathrm{N}$ that plants preferentially use (Bijlsma et al., 2000), and both $\mathrm{NO}_{3}{ }^{-}$and $\mathrm{NH}_{4}{ }^{+}$may comprise about $70 \%$ of the total cations and anions taken up by plants (Beusichem et al., 1988). The form of $\mathrm{N}$ preferred by a tree is not necessarily the most easily absorbed one (Arnold and Diest, 1991), such that plants which grow better with $\mathrm{NO}_{3}{ }^{-}$may absorb more $\mathrm{NH}_{4}{ }^{+}$ instead (Kronzucker et al., 2003). For this reason, dry mass accumulation may be considered a more robust indicator of $\mathrm{N}$ preference than the rate of absorption (e.g. Gigon and Rorison, 1972; Rorison, 1985; Falkengren-Grerup and Lakenborg-Kristensen, 1994), even though dry mass accumulation alone does not inform us about the plasticity required by a plant to cope with different $\mathrm{N}$ forms. Other variables related to $\mathrm{N}$ metabolism, such as nitrate reductase activity (NRA), chlorophyll concentration, root morphology and resource allocation are important for understanding the growth regulation processes of a given plant species when exposed to different forms of inorganic $\mathrm{N}$.

Simões (1973) demonstrated the major impact of $\mathrm{N}$ availability on the initial growth of $A$. angustifolia, and Franco et al. (2005) quantified carbon (C) and $\mathrm{N}$ in leaves, roots and stems of young and mature individuals and showed that, particularly for young plants, roots are important reservoirs of these elements. Duarte and Dillenburg (2000) detected very low NRA in young plants and found that the activity was concentrated in the roots, suggesting a $\mathrm{NH}_{4}{ }^{+}-\mathrm{N}$ preference by the species. These studies indicate an important role of roots in the $\mathrm{C}$ and $\mathrm{N}$ metabolism of the species. In the present study, we aimed to establish whether $A$. angustifolia shows a preference for a given form of inorganic $\mathrm{N}$, by comparing growth and other selected physiological processes among young plants growing under sole or combined nutrition with $\mathrm{NO}_{3}{ }^{-}-\mathrm{N}$ and $\mathrm{NH}_{4}{ }^{+}-\mathrm{N}$. Given the existing evidence that $\mathrm{N}$ metabolism is mostly concentrated in roots, it is hypothesized that ammonium is the $\mathrm{N}$ form that promotes the greatest growth of $A$. angustifolia.

\section{MATERIALS AND METHODS}

Growth conditions: The experiment was conducted in a glass greenhouse of the Soil Department, Federal University of Rio Grande do Sul (30001' S, 51013' W, 4 m a.s.l.), Brazil, without temperature and humidity controls. Commercially obtained seeds from São Francisco de Paula (29024' S, 50²2' W, $912 \mathrm{~m}$ a.s.l.), Rio Grande do Sul State, Brazil, were disinfested with a $2.5 \%$ solution of sodium hypochloride for $30 \mathrm{~min}$, and thoroughly rinsed in distilled water thereafter. The upper third (radicle-protruding region) of the seed had its external covers removed to accelerate germination (Áquila and Ferreira, 1984). Germination took place in plastic trays filled with wet, autoclaved $\left(120^{\circ} \mathrm{C}\right.$ for $\left.1 \mathrm{~h}\right)$ vermiculite, under laboratory conditions. After $10 \mathrm{~d}$, germinated seeds (radicle length with $6 \pm 0.58 \mathrm{~cm}$; mean $\pm \mathrm{SD}$ ) were planted in PVC tubes (height $=45 \mathrm{~cm}$; diameter $=10 \mathrm{~cm}$ ), which allowed 
free drainage through the bases. Sand (36\% fine - $\varnothing=0.05$ - $0.2 \mathrm{~mm}$ - and $64 \%$ coarse - $\varnothing=0.2-2.0 \mathrm{~mm}$ - sand, according to analyses performed by the Soil Department of Federal University of Rio Grande do Sul, Brazil) was used as substrate for plant growth to prevent $\mathrm{NH}_{4}{ }^{+}$adsorption to solid particles (Arnold and Diest, 1991). Sand was washed thoroughly and sequentially using tap water, distilled water, $\mathrm{HCl}$ solution (pH 2.8) and again with distilled water. Each pot was filled with $3.8 \mathrm{~kg}$ of sand.

Experimental design: Growing plants were fed with three different nutrient solutions, all based on a modified Hoagland and Arnon (Taiz and Zeiger, 2004) nutrient solution (Table 1). These solutions differ from each other in terms of the supplied $\mathrm{N}$ form(s): combined supply of $\mathrm{NO}_{3}^{-}{ }^{-} \mathrm{N}$ and $\mathrm{NH}_{4}{ }^{+}-\mathrm{N}^{-}\left(\mathrm{NO}_{3}{ }^{-}\right.$ $+\mathrm{NH}_{4}{ }^{+}$treatment); only $\mathrm{NO}_{3}^{-}-\mathrm{N}$ ( $\mathrm{NO}_{3}^{-}$treatment); and only $\mathrm{NH}_{4}{ }^{+}-\mathrm{N}$ ( $\mathrm{NH}_{4}{ }^{+}$treatment). In all cases, concentration of total $\mathrm{N}$ was kept the same (4 mM) and $\mathrm{pH}$ was adjusted to 5.1. Ionic strength, concentration and activity of each component, and charge differences of the nutrient solutions were checked using Visual Minteq V. 2.30 (Allison et al., 1991; Gustafsson, 2004).

Table 1. Composition and concentrations (mM) of each of the three nutrient solutions used in the study. Micronutrients $\left(\mathrm{mg} \mathrm{L}^{-1}\right)$ : $\mathrm{B}\left(\mathrm{H}_{3} \mathrm{BO}_{3}\right) 0.541 ; \mathrm{Cu}$ $\left(\mathrm{CuSO}_{4} \cdot 5 \mathrm{H}_{2} \mathrm{O}\right)$ 0.032; $\mathrm{FeEDTA}\left(\mathrm{FeSO}_{4} \cdot 7 \mathrm{H}_{2} \mathrm{O}+\mathrm{NaEDTA}\right) 65 ; \mathrm{Mn}\left(\mathrm{MnSO}_{4} \cdot \mathrm{H}_{2} \mathrm{O}\right)$ 0.11; $\mathrm{Mo}\left(\mathrm{H}_{2} \mathrm{MO}_{4} \mathrm{O}_{4}\left[85 \% \mathrm{MoO}_{3}\right]\right) 0.048 ; \mathrm{Zn}\left(\mathrm{ZnSO}_{4} \cdot 7 \mathrm{H}_{2} \mathrm{O}\right)$ 0.131. Other salts used in the nutrient solutions: $\mathrm{KNO}_{3}, \mathrm{NH}_{4} \mathrm{H}_{2} \mathrm{PO}_{4}, \mathrm{KCl}, \mathrm{CaCl}_{2}, \mathrm{KH}_{2} \mathrm{PO}_{4}$, and $\mathrm{MgSO}_{4}$.

\begin{tabular}{cccc}
\hline \multirow{2}{*}{ Nutrients } & \multicolumn{3}{c}{ Treatments } \\
\cline { 2 - 4 } & $\mathrm{NO}_{3}{ }^{-}$ & $\mathrm{NH}_{4}{ }^{+}$ & $\mathrm{NO}_{3}{ }^{-}+\mathrm{NH}_{4}{ }^{+}$ \\
\hline $\mathrm{NO}_{3}{ }^{-} \mathrm{N}$ & 4 & - & 2 \\
$\mathrm{NH}_{4}{ }^{+}-\mathrm{N}$ & - & 4 & 2 \\
$\mathrm{P}$ & 4 & 4 & 4 \\
$\mathrm{~K}$ & 8 & 4 & 4 \\
$\mathrm{Ca}$ & 2 & 2 & 2 \\
$\mathrm{Mg}$ & 1 & 1 & 1 \\
$\mathrm{~S}$ & 1 & 1 & 1 \\
$\mathrm{Cl}$ & 4 & 8 & 4 \\
\hline
\end{tabular}

Treatments were assigned to 45 experimental units (15 plants per treatment), following a randomized complete block design (five blocks, each consisting of nine plants, grouped together on the greenhouse bench). Pots were watered on a weekly basis ( $400 \mathrm{~mL}$ of distilled water) in the period between planting and first application of the nutrient solutions (starting $54 \mathrm{~d}$ after planting). Nutrient solutions were applied to the sand surface on a weekly basis, alternating one application of $750 \mathrm{~mL}$ (vessel capacity) with another of $100 \mathrm{~mL}$ (winter) or $250 \mathrm{~mL}$ (summer), sufficient amounts to bring substrate to vessel capacity. Before each application of $750 \mathrm{~mL}$, the substrate was washed with $400 \mathrm{~mL}$ of distilled water, applied to the surface, in order to minimize salt accumulation (Pereira et al., 1996) and nitrifying effects in those treatments that received $\mathrm{NH}_{4}{ }^{+}$.

Growth measurements: On a weekly basis, starting on the first day of nutrient solution application, plant height and total shoot length (height plus length of lateral branches) were measured. After $290 \mathrm{~d}$ (from planting day), the experiment ended and plants were harvested. Oven-dried $\left(50^{\circ} \mathrm{C}\right)$ mass (total, shoot, and main and lateral roots), basal and apical stem diameters, and main (tap) root length were evaluated. The number and length of first order lateral roots per unit of main root length, and the number of second order roots per unit of first order root length were also measured. A sample of 20 mature leaves of each plant was collected for leaf mass per area (LMA) determination, using a portable leaf area meter (LI3000, LI-COR, Lincoln, USA) for the leaf area measurements.

Chlorophyll concentration: Samples of $20 \quad\left(\mathrm{NO}_{3}{ }^{-}\right.$ treatment) or nine $\left(\mathrm{NH}_{4}{ }^{+}\right.$treatment) apical leaves from the topmost lateral branches were collected for chlorophyll ( $a, b$ and total) measurements. Young leaves were selected because they appeared much paler than the others, particularly in the $\mathrm{NO}_{3}{ }^{-}$treatment. Chlorophyll was extracted with $100 \%$ ethanol (Knudson et al., 1977). The analyses of absorbance (649 and $665 \mathrm{~nm}$ ) were made with a spectrophotometer (Cintra 5 GBC UV-VIS, Victoria, Australia). Chlorophyll concentration was calculated according to Wintermans and De Mots (1965), and expressed on a leaf dry mass basis.

Nitrate reductase activity: The in vivo NRA was measured $2 \mathrm{~d}$ after the last nutrient solution application, according to Klumpp et al. (1989) and Duarte and Dillenburg (2000). Light conditions prior to analysis were the same for all sample units. Briefly, from each plant, 0.4-g-samples of both fresh mature leaves and root tips were taken. Plant material was sliced (ca. $4 \mathrm{~mm}^{2}$ of area), placed in test tubes and mixed with $5 \mathrm{~mL}$ of Sörensen phosphate buffering solution $\left(\mathrm{pH} 7.5, \mathrm{KNO}_{3} 0.1\right.$ $\mathrm{M}$ and isopropanol $1 \%$ ). Tubes were then incubated at $27^{\circ} \mathrm{C}$ in a vacuum oven (VT 5042 EK, Heraeus, Hanau, Germany) for $2 \mathrm{~h}$. To $1 \mathrm{~mL}$ of solution from each tube, $1 \mathrm{~mL}$ of $1 \%$ sulfonilamide in $1 \mathrm{~N} \mathrm{HCl}$ and $1 \mathrm{~mL}$ of a $0.01 \% \mathrm{~N}$-(1-naphtyl) ethylenediamine dihydrocloride were added. Thirty minutes later, the absorbance of the resulting solution was read at 
$540 \mathrm{~nm}$ in a spectrophotometer (SQ300, Merck, Darmstadt, Germany). The remaining solution in each tube was incubated under the same conditions for an additional hour and the above procedure repeated. Enzyme activity was then determined by quantifying the amount of nitrite produced by nitrate reduction after 2 and $3 \mathrm{~h}$ of vacuum incubation (Klumpp et al., 1989).

Carbon and nitrogen measurements: Carbon and $\mathrm{N}$ in mature leaves were quantified in samples of five leaves collected from lateral branches of the second (from the top) whorl of branches. For young leaves, determinations were made in several apical leaves $(\sim 50 \mathrm{~g})$ collected from young branches. Carbon and $\mathrm{N}$ were also quantified in lateral roots (all roots from a given plant making up one sample). Samples were oven-dried $\left(50^{\circ} \mathrm{C}\right)$, ground, and then homogenized. Analyses were performed by the Chemistry Institute of the Federal University of Rio Grande do Sul, using a CHN analyzer (Perkin-Elmer 2400, Waltham, USA).

Statistical analyses: Data were submitted to two-way analysis of variance, with randomization test (Pillar and Orlóci, 1996), using the statistical program MultivMinor v. 2.3.17
(Pillar, 2004). Euclidean distance was used as a dissimilarity measure for all data. Means were compared through orthogonal contrasts $(P \leq 0.05)$.

\section{RESULTS}

After $200 \mathrm{~d}$, total shoot length (height plus length of all lateral branches) did not differ between $\mathrm{NH}_{4}{ }^{+}$-fed $(88.2 \pm 5.2$ $\mathrm{cm}$; mean $\pm \mathrm{SE}$ ) and $\mathrm{NO}_{3}+\mathrm{NH}_{4}{ }^{+}$-fed $(85.2 \pm 5.0 \mathrm{~cm})$ plants. However, it was significantly less $(65.8 \pm 5.4 \mathrm{~cm})$ in $\mathrm{NO}_{3}{ }^{-}$-fed plants than in the other two treatments. This pattern remained unchanged until the end of the experiment $(199.9 \pm 13.8$ $\mathrm{cm}$ for $\mathrm{NH}_{4}{ }^{+}$-fed plants; $187.9 \pm 9.4 \mathrm{~cm}$ for $\mathrm{NO}_{3}{ }^{-}+\mathrm{NH}_{4}{ }^{+}$-fed plants; and $99.8 \pm 7.8 \mathrm{~cm}$ for $\mathrm{NO}_{3}{ }^{-}$-fed plants; $P \leq 0.05$ ). Plants receiving $\mathrm{NH}_{4}{ }^{+}$had greater shoot and total biomass accumulation (Figure 1) than those that only received $\mathrm{NO}_{3}$. Plants receiving $\mathrm{NO}_{3}{ }^{-}$, on the other hand, accumulated more root biomass than the others, because of their greater mass investment in the main tap root (mass of lateral roots did not differ among treatments).

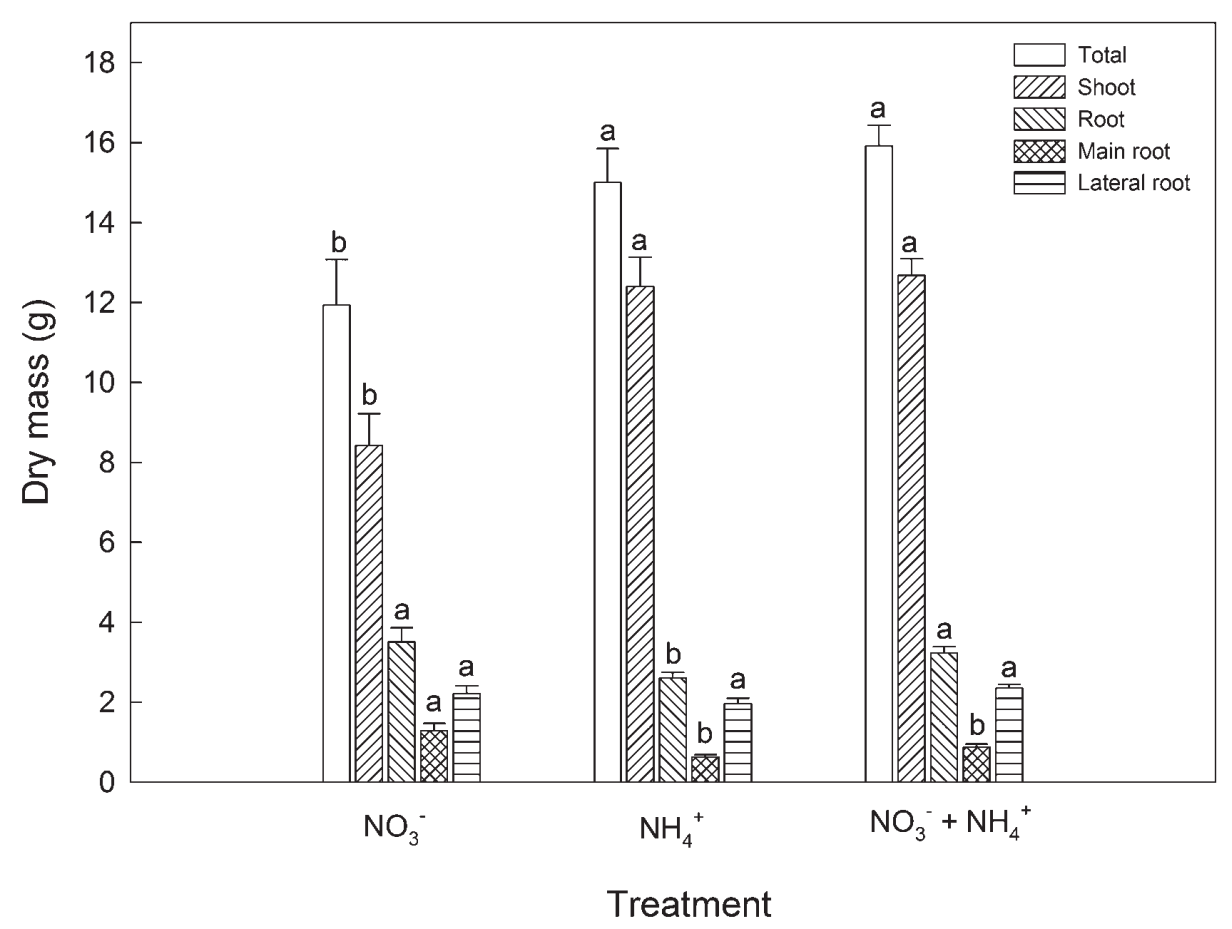

Figure 1. Dry mass accumulation in Araucaria angustifolia plants growing under different inorganic nitrogen sources. Vertical bars and lines are means and standard errors, respectively. For a given measurement, different letters indicate significant differences between treatment means $(P<0.001$ for shoot biomass; $P<0.05$ for the other parameters). 
Nitrate-fed plants had a higher root:shoot mass ratio than plants from the other two treatments, and a lower mass ratio between lateral roots and the main root than the $\mathrm{NH}_{4}{ }^{+}$-fed plants. When ratios of root length and number were considered, however, plants of the $\mathrm{NO}_{3}{ }^{-}$treatment clearly showed a higher degree of root ramification, particularly when compared to plants fed only with $\mathrm{NH}_{4}{ }^{+}$(Table 2). Plants fed only with $\mathrm{NO}_{3}{ }^{-}$also displayed a pronounced thickening of the stem apexes, smaller leaves, as well as higher LMA of both mature and young leaves, when compared to plants receiving $\mathrm{NH}_{4}{ }^{+}$ (Table 2), giving them a highly scleromorphic appearance. Differences in LMA were much more pronounced for young leaves, to the point that young leaves of $\mathrm{NO}_{3}^{-}$-treatment plants reached a higher LMA than the corresponding mature leaves (Table 2). Plants from this treatment also showed visible chlorosis of apical young leaves, as attested by their lower chlorophyll concentrations, especially when compared to young leaves of plants in the $\mathrm{NH}_{4}{ }^{+}$-treatment (Table 3). Additionally, $\mathrm{NO}_{3}^{-}$-treated plants also accumulated less $\mathrm{C}$ and $\mathrm{N}$ in young leaves than did plants of the other treatments.
Because differences in $\mathrm{N}$ were much greater than differences in $\mathrm{C}$ concentration, young leaves of $\mathrm{NO}_{3}^{-}$-treatment plants had a higher $\mathrm{C}: \mathrm{N}$ ratio than the corresponding leaves of the other two treatments. These treatment differences in $\mathrm{C}$ and $\mathrm{N}$ did not extend to mature leaves. Feeding of plants with $\mathrm{NO}_{3}^{-}$(singly or not) resulted in lower $\mathrm{N}$ concentration and higher $\mathrm{C}: \mathrm{N}$ ratio of lateral roots, compared to plants receiving only $\mathrm{NH}_{4}{ }^{+}$(Table 3). Interestingly, plants that received only $\mathrm{NH}_{4}{ }^{+}$had similar $\mathrm{C}$ and $\mathrm{N}$ concentrations in all measured plant fractions (leaves and roots), in strong opposition to those that received only $\mathrm{NO}_{3}{ }^{-}$, which showed less $\mathrm{C}$ and $\mathrm{N}$ in young leaves and lateral roots than in mature leaves.

In all treatments, NRA was much higher in roots than in leaves (only about 3 to $13 \%$ of total NRA was expressed in leaves). As expected, root NRA was much higher in plants that received only $\mathrm{NO}_{3}{ }^{-}$than in the others. Surprisingly, plants that received $\mathrm{NH}_{4}{ }^{+}$, either singly or in combination with $\mathrm{NO}_{3}{ }^{-}$, showed higher levels of NRA in leaves than those that were fed only with $\mathrm{NO}_{3}^{-}$(Table 3 ).

Table 2. Additional morphological parameters of Araucaria angustifolia plants growing under different inorganic nitrogen sources. Data are means \pm SE. Different small letters indicate significant differences in the rows $(P \leq 0.05 ; P<0.001$ for root:shoot ratio). For leaf mass per area (LMA), different capital letters indicate significant differences in the columns $(P \leq 0.003) ; n=14$ for $\mathrm{NO}_{3}{ }^{-}$treatment, and $n=15$ for $\mathrm{NH}_{4}{ }^{+}$e $\mathrm{NO}_{3}{ }^{-}+\mathrm{NH}_{4}{ }^{+}$treatments. However, for N1, N2, CRP and C1, $n$ $=10$ for $\mathrm{NO}_{3}^{-}$treatment, and $n=11$ for $\mathrm{NH}_{4}{ }^{+}$and $\mathrm{NO}_{3}{ }^{-}+\mathrm{NH}_{4}{ }^{+}$treatments; and for LMA of young leaves, $n=11$ for $\mathrm{NO}_{3}{ }^{-}, n=13$ for $\mathrm{NH}_{4}{ }^{+}$, and $n=15$ for $\mathrm{NO}_{3}{ }^{-}+$ $\mathrm{NH}_{4}{ }^{+}$treatments. $\mathrm{N} 1$ = total number of first order lateral roots; $\mathrm{MRL}=$ main root length; $\mathrm{N} 2=$ total number of second order lateral roots; $\mathrm{L} 1=$ total length of first order lateral roots.

\begin{tabular}{|c|c|c|c|}
\hline \multirow{2}{*}{ Parameters } & \multicolumn{3}{|c|}{ Treatments } \\
\hline & $\mathrm{NO}_{3}^{-}$ & $\mathrm{NH}_{4}^{+}$ & $\mathrm{NO}_{3}^{-}+\mathrm{NH}_{4}^{+}$ \\
\hline Root: shoot $\left(\mathrm{g} \mathrm{g}^{-1}\right)$ & $0.46 \pm 0.02 \mathrm{a}$ & $0.21 \pm 0.01 b$ & $0.26 \pm 0.01 b$ \\
\hline Lateral root : main root $\left(\mathrm{g} \mathrm{g}^{-1}\right)$ & $1.99 \pm 0.19 b$ & $3.64 \pm 0.51 \mathrm{a}$ & $2.91 \pm 0.24 \mathrm{ab}$ \\
\hline $\mathrm{N} 1: \operatorname{MRL}\left(\mathrm{n}^{0} \mathrm{~cm}^{-1}\right)$ & $1.51 \pm 0.11 \mathrm{a}$ & $1.18 \pm 0.07 b$ & $1.26 \pm 0.06 a b$ \\
\hline $\mathrm{N} 2: \mathrm{L} 1\left(\mathrm{n}^{0} \mathrm{~cm}^{-1}\right)$ & $0.33 \pm 0.06 \mathrm{a}$ & $0.10 \pm 0.03 b$ & $0.17 \pm 0.03 b$ \\
\hline L1: MRL $\left(\mathrm{cm} \mathrm{cm}^{-1}\right)$ & $9.36 \pm 0.86 a$ & $6.69 \pm 0.66 b$ & $7.45 \pm 0.39 a b$ \\
\hline Apical stem diameter (mm) & $6.90 \pm 0.35 a$ & $4.49 \pm 0.15 b$ & $5.24 \pm 0.23 b$ \\
\hline Basal stem diameter (mm) & $6.31 \pm 0.22 \mathrm{a}$ & $6.47 \pm 0.13 a$ & $6.48 \pm 0.13 a$ \\
\hline LMA mature leaves $\left(\mathrm{g} \mathrm{m}^{-2}\right)$ & $102.6 \pm 2.7 \mathrm{aB}$ & $90.8 \pm 1.9 \mathrm{bA}$ & $92.1 \pm 1.4 \mathrm{bA}$ \\
\hline LMA young leaves $\left(\mathrm{g} \mathrm{m}^{-2}\right)$ & $120.9 \pm 4.5 \mathrm{aA}$ & $63.3 \pm 4.8 \mathrm{cB}$ & $82.6 \pm 2.7 b B$ \\
\hline Size mature leaves $\left(\mathrm{cm}^{2}\right)$ & $0.57 \pm 0.05 b$ & $0.67 \pm 0.02 \mathrm{a}$ & $0.70 \pm 0.03 a$ \\
\hline Size young leaves $\left(\mathrm{cm}^{2}\right)$ & $0.20 \pm 0.01 b$ & $0.80 \pm 0.13 a$ & $0.62 \pm 0.04 \mathrm{a}$ \\
\hline
\end{tabular}


Table 3. Chlorophyll, carbon $(\mathrm{C})$ and nitrogen $(\mathrm{N})$ concentrations, and nitrate reductase activity (NRA) in Araucaria angustifolia plants growing under different inorganic $\mathrm{N}$ sources. Data are means $\pm \mathrm{SE}$. Different small letters indicate significant differences in the rows $(P \leq 0.05 ; P<0.08$ for NRA). Different capital letters indicate significant differences in the columns $(P \leq 0.05) ; n=14$ for $\mathrm{NO}_{3}{ }^{-}$treatment, and $n=15$ for $\mathrm{NH}_{4}{ }^{+}$and $\mathrm{NO}_{3}{ }^{-}+\mathrm{NH}_{4}{ }^{+}$treatments; however, $n=4-5$ for $\mathrm{C}, \mathrm{N}$ e C:N determinations.

\begin{tabular}{|c|c|c|c|}
\hline \multirow{2}{*}{ Parameters } & \multicolumn{3}{|c|}{ Treatments } \\
\hline & $\mathrm{NO}_{3}{ }^{-}$ & $\mathrm{NH}_{4}^{+}$ & $\mathrm{NO}_{3}^{-}+\mathrm{NH}_{4}^{+}$ \\
\hline \multicolumn{4}{|c|}{ Chlorophyll young leaves $\left(\mathrm{mg} \mathrm{g}^{-1}\right)$} \\
\hline a & $1.78 \pm 0.11 b$ & $3.29 \pm 0.18 a$ & $2.34 \pm 0.26 b$ \\
\hline$b$ & $0.76 \pm 0.11 b$ & $1.17 \pm 0.07 \mathrm{a}$ & $0.91 \pm 0.12 \mathrm{ab}$ \\
\hline Total & $2.54 \pm 0.20 b$ & $4.46 \pm 0.22 \mathrm{a}$ & $3.25 \pm 0.37 \mathrm{ab}$ \\
\hline$a: b$ ratio & $2.75 \pm 0.31 \mathrm{a}$ & $2.88 \pm 0.18 a$ & $2.65 \pm 0.18 \mathrm{a}$ \\
\hline \multicolumn{4}{|l|}{ Carbon (\%) } \\
\hline Mature leaves & $45.1 \pm 0.2 \mathrm{aA}$ & $45.9 \pm 0.3 \mathrm{aA}$ & $45.3 \pm 0.4 \mathrm{aA}$ \\
\hline Young leaves & $43.8 \pm 0.3 \mathrm{bAB}$ & $45.7 \pm 0.2 \mathrm{aA}$ & $45.2 \pm 0.2 \mathrm{aA}$ \\
\hline Lateral roots & $40.7 \pm 1.6 \mathrm{aB}$ & $42.8 \pm 1.8 \mathrm{aA}$ & $40.7 \pm 1.3 \mathrm{aB}$ \\
\hline \multicolumn{4}{|l|}{ Nitrogen (\%) } \\
\hline Mature leaves & $2.46 \pm 0.09 \mathrm{aA}$ & $2.47 \pm 0.23 \mathrm{aA}$ & $2.32 \pm 0.10 \mathrm{aA}$ \\
\hline Young leaves & $1.79 \pm 0.08 \mathrm{bB}$ & $2.52 \pm 0.07 \mathrm{aA}$ & $2.21 \pm 0.15 a b A$ \\
\hline Lateral roots & $1.48 \pm 0.11 \mathrm{bB}$ & $2.60 \pm 0.21 \mathrm{aA}$ & $1.52 \pm 0.09 \mathrm{bB}$ \\
\hline \multicolumn{4}{|l|}{ C:N ratio (\%) } \\
\hline Mature leaves & $18.5 \pm 0.8 \mathrm{aB}$ & $19.0 \pm 1.7 \mathrm{aA}$ & $19.7 \pm 1.0 \mathrm{aB}$ \\
\hline Young leaves & $24.7 \pm 1.2 \mathrm{aAB}$ & $18.2 \pm 0.6 \mathrm{bA}$ & $20.8 \pm 1.4 \mathrm{bB}$ \\
\hline Lateral roots & $28.3 \pm 3.6 \mathrm{aA}$ & $16.7 \pm 0.9 \mathrm{bA}$ & $27.0 \pm 1.4 \mathrm{aA}$ \\
\hline \multicolumn{4}{|l|}{$\begin{array}{l}\text { NRA } \\
\left(\mathrm{nmol} \mathrm{NO}{ }_{2}^{-} \mathrm{g}^{-1} \mathrm{~h}^{-1}\right)\end{array}$} \\
\hline Leaves & $6.4 \pm 1.5 \mathrm{bB}$ & $22.3 \pm 5.6 \mathrm{aB}$ & $18.2 \pm 3.2 \mathrm{aB}$ \\
\hline Roots & $169.4 \pm 26.4 \mathrm{aA}$ & $91.8 \pm 13.8 \mathrm{bA}$ & $117.2 \pm 27.5 \mathrm{bA}$ \\
\hline
\end{tabular}

\section{DISCUSSION}

Although the species distribution is typically restricted to tropical and subtropical regions, the results show that A. angustifolia shares with temperate climate conifers the preference for $\mathrm{NH}_{4}{ }^{+}$as inorganic $\mathrm{N}$ source. Nitrate, when provided alone, induced symptoms of $\mathrm{N}$ deficiency. These symptoms included overall reduction of plant growth, larger root:shoot mass ratio, root branching and LMA, leaf size reduction, stem thickening, and less mass-based chlorophyll and $\mathrm{N}$ concentrations in the young leaves, when compared to plants which received $\mathrm{NH}_{4}{ }^{+}$. Many of these aspects were responsible for the scleromorphic appearance shown by those plants. Araucaria angustifolia exhibited $\mathrm{N}$ deficiency symptoms when submitted to a long period (180 d) of $\mathrm{NO}_{3}^{-}$-based nutrition. The scleromorphic appearance of the $\mathrm{NO}_{3}$-treated plants has similarities to field plants growing under full sunlight conditions. This field scleromorphism may be related to an imbalance in $\mathrm{C}$ and $\mathrm{N}$ assimilation, mostly due to a high $\mathrm{C}$ assimilation not matched by proper $\mathrm{N}$ assimilation.
Leaf $\mathrm{N}$ deficiency and associated $\mathrm{NO}_{3}$-induced responses, such as chlorosis, were more evident in young than in mature leaves, indicating a possible limitation on the process of translocation of organic $\mathrm{N}$ from mature to young leaves. Consistent with this scenario is the fact that, in contrast to what would be expected (Mediavilla and Escudero, 2003), young leaves of $\mathrm{NO}_{3}^{-}$-fed plants had lower $\mathrm{N}$ concentrations than mature leaves. Although not tested in this study, this pattern could also be associated with apoplast alkalization caused by possible $\mathrm{NO}_{3}{ }^{-} / \mathrm{H}^{+}$co-transport in the process of leaf cell $\mathrm{N}$ absorption, followed by depression in $\mathrm{Fe}^{3+}$ reduction and by leaf chlorosis induced by iron deficiency (Kosegarten et al., 1999).

Nitrate is an important regulatory molecule acting on cellular processes related to plant growth (Crawford, 1995). Despite the lower mass ratio between lateral roots and the main root exhibited by the $\mathrm{NO}_{3}$-fed plants (forced by a great investment in the main root), these plants had a more intense branched root system than those fed only with $\mathrm{NH}_{4}{ }^{+}$, indicating that root architecture, which plays a central role in resource 
acquisition by plants (Fitter, 1994), was much more affected by the different treatments than root mass. We suggest that $\mathrm{NO}_{3}^{-}$plays an important role in regulating root branching in A. angustifolia and that this ramification ability may favor the access to patchily distributed soil resources.

Consistent with the species preference for $\mathrm{NH} 4+$, the NRA root:shoot partitioning in $A$. angustifolia was also that expected for temperate climate conifers (Andrews, 1986), with most of the activity concentrated in the roots. These results support the suggestions made by Franco et al. (2005) that most of the $\mathrm{N}$ taken up from the soil is metabolized in the roots, and is consistent with the results of Duarte and Dillenburg (2000), who detected NRA only in the roots of $A$. angustifolia. Our study to the best of our knowledge, presents the first evidence of leaf NRA in this species. Leaf NRA is typically low in gymnosperms under natural conditions and was shown to increase when $\mathrm{NO}_{3}^{-}$was supplied at $5 \mathrm{mM}$, thus increasing the importance of the shoot to whole plant $\mathrm{N}$ assimilation (Smirnoff et al., 1984; Andrews, 1986; Stewart et al., 1992). The supply of significant amounts of $\mathrm{NO}_{3}^{-}$may then explain the leaf activity of $\mathrm{NO}_{3}^{-}$reduction reported in this study. Araucaria angustifolia may carry out most of its NRA in the roots under natural conditions, where low levels of inorganic $\mathrm{N}$ are found (Garbin et al., 2006).

As expected (Oaks and Stevens, 1972; Stewart et al., 1992), NRA in roots was higher when the supply of $\mathrm{NO}_{3}{ }^{-}$was also greater. The observed NRA in the $\mathrm{NH}_{4}{ }^{+}$-treated plants, however, could indicate contamination of the growth medium by nitrifying agents or constitutive levels of enzyme activity. Sand cultures using $\mathrm{NH}_{4}{ }^{+}$-based nutrient solutions may show relatively high levels of nitrifying activity (Padgett and Leonard, 1993), and even a low $\mathrm{NO}_{3}^{-}$concentration may induce some NRA (Tischner, 2000). Although nitrification was not evaluated in the $\mathrm{NH}_{4}{ }^{+}$treatment, it is reasonable to expect that the weekly applications of the nutrient solutions ensured the continuous presence of large amounts of $\mathrm{NH}_{4}{ }^{+}$in the system, while the periodic washing of the substrate alleviated any $\mathrm{NO}_{3}{ }^{-}$ accumulation due to nitrification. Although growth parameters were not likely to be strongly influenced by such nitrification, NRA of $\mathrm{NH}_{4}{ }^{+}$-treated plants were expected to significantly respond to any presence of $\mathrm{NO}_{3}{ }^{-}$due to nitrification. While both a possible contamination effect and/or a constitutive activity may help to explain the NRA in plants fed only with $\mathrm{NH}_{4}{ }^{+}$, it does not account for the greater leaf NRA activity in these plants, when compared to those receiving only $\mathrm{NO}_{3}$. In vivo NRA essays with $\mathrm{NO}_{3}{ }^{-}$(as used in the present study) only use endogenous NAD(P)H as source of energy for enzyme activity (Andrews, 1986; Li and Gresshoff, 1990). The low leaf NRA of $\mathrm{NO}_{3}$-treatment plants could possibly be explained by a lack of energy caused by the $\mathrm{NO}_{3}$-imposed $\mathrm{N}$ deficiency.

Two additional methodological problems must also be considered in this discussion: (1) $\mathrm{N}$ concentration in the applied solutions (4 mM) was probably high, especially considering the intrinsic slow growth of the species, and (2) there was no pH control of the growth medium, only of the nutrient solutions. The $\mathrm{N}$ concentration in the applied solutions may appear high when compared to concentrations found in the upper horizons of soils where the species naturally occur (mean concentrations of $3-21 \mathrm{mg} \mathrm{kg}^{-1}$ in a native forest; Garbin et al., 2006). However, it is lower than those used in experiments that examined the effects of high $\mathrm{N}$ supply in conifers (e.g. Flaig and Mohr, 1992). These concentrations are useful starting points, because, as long as they do not generate serious toxic effects, they ensure that the availability of nutrients will not limit plant growth. Furthermore, other experiments have shown that the species can sustain growth under $\mathrm{N}$ concentrations of up to $16 \mathrm{mM}$ (C. Clebsch and L. R. Dillenburg, unpublished results). The $\mathrm{pH}$ variation in the growth medium, which could have potentially altered nutrient availability, probably had a small effect, given the high concentration of the solutions and their frequent applications (every week).

Based on growth parameters, we conclude that $\mathrm{NH}_{4}{ }^{+}$was preferred over $\mathrm{NO}_{3}{ }^{-}$by young plants of $A$. angustifolia. Nitrate, however, seemed to play an important role in regulating plant growth and N metabolism. Garbin et al. (2006) found strikingly different patterns of spatial distribution of inorganic $\mathrm{N}$ in three plant communities of southern Brazil: a native forest, a Pinus plantation and a native grassland. Though $A$. angustifolia is able to establish itself in all of these plant communities, the authors found that the native forest differed from the others in that $\mathrm{NO}_{3}{ }^{-}$, instead of $\mathrm{NH}_{4}{ }^{+}$, was the major inorganic $\mathrm{N}$ form. It would be expected that soils which do not have $\mathrm{NH}_{4}{ }^{+}$as a major $\mathrm{N}$ form would limit the performance of $A$. angustifolia. However, although the soil under well-developed, mature forests has $\mathrm{NO}_{3}{ }^{-}$as the major inorganic $\mathrm{N}$ form, it does not exclude the presence of $\mathrm{NH}_{4}^{+}$and it is associated to a lowirradiance understory, which limits overall plant growth. The 
two inorganic $\mathrm{N}$ forms $\mathrm{co}-\mathrm{occur}$ in natural soils and only their proportions vary in response to environmental factors, such as temperature, soil pH, humidity, and soil C:N ratio.

Unlike temperate climate forest ecosystems, characterized by an increase in the ratio of $\mathrm{NH}_{4}{ }^{+}$over $\mathrm{NO}_{3}{ }^{-}$as succession proceeds (Rice and Pancholy, 1973; Kronzucker et al., 2003), this ratio is greater in grasslands than in the late successional Araucaria forests (Garbin et al. 2006). Araucaria angustifolia, the dominant plant species in these forests, but also one of the first tree species to invade the adjacent grasslands (Duarte et al., 2006), prefers ammonium over nitrate, at least during initial growth. This preference can make grasslands better suited for the successful establishment of the species than the forest understory itself.

We conclude this report suggesting three different approaches to be taken in the future, in order to better characterize the $\mathrm{N}$ nutrition of the species: (1) to measure its relative growth performance when growing in natural environments that differ both in the proportion of these inorganic $\mathrm{N}$ forms and in irradiance; (2) to assess the possible use of organic $\mathrm{N}$ forms, a use that has already been characterized for other conifers (e.g. Näsholm and Persson, 2001); and (3) to evaluate the impact of inorganic $N$ supply on mycorrhiza, an association to which $A$. angustifolia was found to be highly dependent on (Moreira-Souza and Cardoso, 2002; Zandavalli et al., 2004), and whose effects on plant growth are highly dependent on the form of inorganic $\mathrm{N}$ supplied to the plant (Bledsoe and Zasoski 1983).

Acknowledgements: We thank Arthur G. Fett Neto, Humberto Bohnen, Luís Mauro G. Rosa and Verônica A. Pardo for helpful suggestions to this study, the Soil Department of the Federal University of Rio Grande do Sul for providing greenhouse space, CAPES/Brazil and CNPq/Brazil for the graduate and research fellowships awarded, respectively, to the first and second author, and FAPERGS/Brazil and CNPq/Brazil for partial financial support.

\section{REFERENCES}

Allison JD, Brown DS, Novo-Gradac KJ (1991) MINTEQA2/PRODEFA2: a geochemical assessment model for environmental systems: version 3.00 users manual. United States Environmental Protection Agency, Athens.
Andrews M (1986) The partitioning of nitrate assimilation between root and shoot of higher plants. Plant Cell Environ. 9:511-519.

Áquila MEA, Ferreira AG (1984) Germinação de sementes escarificadas de Araucaria angustifolia em solo. Cienc. Cult. 36:1583-1589.

Arnold G, van Diest A (1991) Nitrogen supply, tree growth and soil acidification. Fert. Res. 27:29-38.

Beusichem ML, Kirkby EA, Baas R (1988) Influence of nitrate and ammonium nutrition on the uptake, assimilation, and distribution of nutrients in Ricinus communis. Plant Physiol. 86:914-921.

Bijlsma RJ, Lambers H, Kooijman SALM (2000) A dynamic whole-plant model of integrated metabolism of nitrogen and carbon. 1. Comparative ecological implications of ammonium-nitrate interactions. Plant Soil. 220:49-69.

Bledsoe CS, Zasoski RJ (1983) Effects of ammonium and nitrate on growth and nitrogen uptake by mycorrhizal Douglas-fir seedlings. Plant Soil. 71:445454.

Crawford NM (1995) Nitrate: nutrient and signal for plant growth. Plant Cell. 7:859-868.

Duarte LS, Dillenburg LR (2000) Ecophysiological responses of Araucaria angustifolia (Araucariaceae) seedlings to different irradiance levels. Austr. J. Bot. 48:531-537.

Duarte LS, Machado RE, Hartz SM, Pillar VD (2006) What saplings can tell us about forest expansion over natural grasslands. J. Veg. Sci. 17:799-808.

Falkengren-Grerup U, Lakkenborg-Kristensen H (1994) Importance of ammonium and nitrate to the performance of herb-layer species from deciduous forest in southern Sweden. Environ. Exp. Bot. 34: 31-38.

Fitter AH (1994) Architecture and biomass allocation as components of the plastic response of root systems to soil heterogeneity. In: Caldwell MM, Pearcy RW (eds), Exploitation of Environmental Heterogeneity by Plants: Ecophysiological Processes Above- and Belowground, pp.305-323. Academic Press, San Diego.

Flaig H., Mohr H (1992) Assimilation of nitrate and ammonium by the Scots pine (Pinus sylvestris) seedling under conditions of high nitrogen supply. Physiol. Plant. 84:568-576.

Franco AC, Duarte HM, Geßler A, de Mattos EA, Nahm M, Rennemberg H, Ribeiro KT, Scarano FR, Lüttge U (2005) In situ measurements of carbon and nitrogen distribution and composition, photochemical efficiency and stable isotope ratios in Araucaria angustifolia. Trees. 19:422-430.

Garbin ML, Zandavalli RB, Dillenburg LR (2006) Soil patches of inorganic nitrogen in subtropical Brazilian plant communities with Araucaria angustifolia. Plant Soil. 286:323-337.

Gigon A, Rorison IH (1972) The response of some ecologically distinct plant species to nitrate- and to ammonium-nitrogen. J. Ecol. 60:93-102.

Gustafsson JP (2004) Visual minteq ver. 2.30. KTH, Stockholm.

Klumpp A, Kuppers K, Guderian R (1989) Nitrate reductase activity of needles of Norway spruce fumigated with different mixture of ozone, sulfur dioxide, and nitrogen dioxide. Environ. Pollut. 58:261-271.

Knudson LL, Tibbilis TW, Edwards GE (1977) Measurement of ozone injury by determination of leaf chlorophyll concentration. Plant Physiol. 60:606-608.

Kosegarten H, Hoffmann B, Mengel K (1999) Apoplastic pH and $\mathrm{Fe}^{3+}$ reduction in intact sunflower leaves. Plant Physiol. 121:1069-1079.

Kronzucker HJ, Siddiqi MY, Glass ADM, Britto DT (2003) Root ammonium transport efficiency as a determinant in forest colonization patterns: a hypothesis. Physiol. Plant. 117:164-170.

Li ZZ, Gresshoff PM (1990) Developmental and biochemical regulation of 'constitutive' nitrate reductase activity in leaves of nodulating soybean. J. Exp. Bot. 41:1231-1238.

Mediavilla S, Escudero A (2003) Relative growth rate of leaf biomass and leaf nitrogen content in several Mediterranean woody species. Plant Ecol. 168:321-332. 
Moreira-Souza M., Cardoso EJBN (2002) Dependência micorrízica de Araucaria angustifolia (Bert.) 0. Ktze. sob doses de fósforo. Rev. Bras. Ciênc. Solo. 26:905-912.

Näsholm T, Persson J (2001) Plant acquisition of organic nitrogen in boreal forests. Physiol. Plant. 111:419-426.

Oaks A, Wallace W, Stevens D (1972) Synthesis and turnover of nitrate reductase in corn roots. Plant Physiol. 50:649-654.

Padgett PE, Leonard RT (1993) Contamination of ammonium-based nutrient solutions by nitrifying organisms and conversion of ammonium to nitrate. Plant Physiol. 101:141-146.

Pereira EG, Siqueira FRV, Moreira FMS (1996) Influência do nitrogênio mineral no crescimento e colonização micorrízica de mudas de árvores. Pesq. Agropec. Bras. 3:653-662.

Pillar VP (2004) MULTIV - multivariate exploratory analysis, randomization testing and bootstrap resampling v. 2.3.10 - user's guide. UFRGS, Porto Alegre.

Pillar VP, Orlóci L (1996) On randomization testing in vegetation science: multifactor comparisons of relevé groups. J. Veg. Sci. 7:585-592.

Rice EL, SK Pancholy (1973) Inhibition of nitrification by climax ecosystems. II. Additional evidence and possible role of tannins. Am. J. Bot. 60:691-702.
Rorison IH (1985) Nitrogen source and the tolerance of Deschampsia flexuosa, Holcus lanatus and Bromus erectus to aluminum during seedling growth. J. Ecol. 73:83-90.

Simões JW (1973) Efeitos da omissão de nutrientes na alimentação mineral do pinheiro do paraná Araucaria angustifolia (Bert.) 0 . Ktze cultivada em vaso. In: Anais do II Congresso Florestal Brasileiro. Curitiba, Brazil, pp.17-21.

Smirnoff N, Todd P, Stewart GR (1984) The occurrence of nitrate reduction in the leaves of woody plants. Ann. Bot. 54:363-374.

Stewart GR, Joly CA, Smirnoff N (1992) Partitioning of inorganic nitrogen assimilation between the roots and shoots of cerrado and forest trees of contrasting plant communities of South East Brazil. Oecologia. 91:511-517.

Taiz, L. and Zeiger, E. (2004) Fisiologia Vegetal. $3^{\text {rd }}$ ed. Artmed, Porto Alegre.

Tischner R (2000) Nitrate uptake and reduction in higher and lower plants. Plant Cell Environ. 23:1005-1024.

Wintermans JFGM, DeMots A (1965) Spectrophotometric characteristics of chlorophylls $a$ and $b$ and their pheophytins in ethanol. Biochim. Biophys. Acta. 109:448-453.

Zandavalli RB, Dillenburg LR, Souza PV (2004) Growth responses of Araucaria angustifolia (Araucariaceae) to inoculation with the mycorrhizal fungus Glomus clarum. Appl. Soil Ecol. 25:245-255. 